\title{
ANALISIS PERBANDINGAN PENGOLAHAN CITRA ASLI DAN HASIL CROPING UNTUK IDENTIFIKASI TELUR
}

By Anton Yudhana 


\author{
Shoffan Saifullah $^{\# 1}$, Sunardi ${ }_{16}^{* 2}$, Anton Yudhana ${ }^{\# 3}$ \\ "Magister Teknik Informatika, Universitas Ahmad Dahlan \\ Jl. Prof. Dr. Soepomo, S.H. Janturan Yogyakarta, 55164, Indonesia. \\ ${ }^{1}$ shoffan seyahoo.com \\ ${ }^{2}$ sunardiemti.uad.ac.id \\ ${ }^{3}$ eyudhanaemti.uad.ac.id
}

\begin{abstract}
Thermal imaging camera and smart phone camera are the impacts of rapid technological development. This research uses two tools to take pictures of chicken eggs. Images of chicken eggs from the both tools are used to identify of size, determination of object and analysis of image cropping from the samples have used. Process analysis using Matlab prototype for image processing began with histogram, converting the image to grayscale or black white, then the process was carried region props, centroid and the bounding box and labelling. Process analysis using Matlab prototype for image processing began with histogram, converting the image to grayscale or black white, then the process is carried region props, centroid, bounding box and labelling. The process of identification egg objects with region props and labelling can be successfully performed with a $100 \%$ success rate. After each of sample images was conducted, it could be shown that the cropping process gave area smaller than original object (chicken eggs). There was equal area of the same object. The identification process on the image of the chicken egg thermal cameras and smart phone cameras give equal areas. However, after each data cropping of the process is done, the image from the thermal cameras and smart phone cameras give different values. So the cropping process provides the differentiation in the identification process of chicken eggs. The differentiation between the image processing of thermal cameras and smart phone cameras was in the pre processing stages. Thermal camera images needed complement process, but smart phone camera images needed opening process before doing the region props and labelling process for object identification.
\end{abstract}

Keywords - Cropping, Complement, Region props and labelling, Centroid and Bounding Box

\section{Pendahuluan}

Perbandingan analisis dalam pengolahan citra dapat dilakukan dengan berbagai parameter, misalnya dengan objek yang akan dianalisis, metode, penerapan alat, tingkat keakuratan, dan lain sebagainya. Proses pencitraan sering dilakukan dengan menggunakan kamera digital, analog, maupun kamera thermal yang saat ini berkembang. Kamera thermal dan kamera digital merupakan alat yang digunakan untuk melakukan pencitraan objek nyata. Perbedaan antara kedua alat tersebut adalah hasil representasi gambar yang dihasilkan dan konsep yang berbeda. Akuisisi citra menggunakan kamera thermal menghasilkan gambar yang merepresentasikan panas yang dipancarkan oleh objek sedangkan kamera digital menghasilkan gambar yang sesuai dengan objek nyata karena menggunakan konsep refleksi bahwa benda yang dicapture akan seperti objek nyatanya.

Thermal Imaging merupakan teknik yang digunakan untuk mengubah energi inframerah (panas) yang dipancarkan oleh objek untuk divisualisasikan[1]. Thermal imaging mempunyai konsep bahwa setiap benda yang berada diatas temperatur $0^{\circ}$ memancarkan energi panas (inframerah).

Seiring dengan perkembangan teknologi, pencitraan digital dapat dilakukan dengan beberapa device mulai dari kamera analog, digital dan bahkan smart phone juga dapat digunakan untuk melakukan proses pencitraan objek. Objek dapat berupa benda mati maupun benda hidup, misalnya adalah tel18 Telur merupakan benda dengan cangkang dan terdapat zat hidup bakal anak yang dihasilkan oleh unggas (ayam, itik, dan sebagainya)[2].

Telur ketika dilakukan pencitraan dengan menggunakan kamera dari thermal imaging dan smart phone akan memberikan gambar yang berbeda. Kamera thermal imaging akan memberikan gambar telur yang menunjukan panas yang dihasilkan oleh telur. Konsep thermal dalam capture telur ayam menjelaskan bahwa telur menghasilkan suhu panas sehingga dalam identifikasi pengolahan citra telur dengan menggunakan thermal imaging camera dapat dilakukan. Penggunaan kamera thermal tidak menimbulkan efek negatif (radiasi) pada telur maupun lingkungan karena tidak memancarkan sinar infra atau gelombang elektromagnetis, tetapi menyerap sinar infra dari panas yang dipancarkan oleh obyek/benda[3]. Sedangkan kamera 
smartphone akan menghasilkan gambar yang sama persis dengan objeknya (refleksi).

Proses analisis pengolahan citra telur dilakukan dengan memanfaatkan kamera dari thermal imaging dan smart phone. Telur merupakan objek nyata yang harus diubah ke dalam citra digital untuk proses pengolahan citra. Sehingga didapatkan 2 citra digital yang berbeda yang akan dilakukan perbandingan pengolahan citra baik citra dari thermal imaging camera maupun citra dari smart phone camera. Kemudian dilakukan proses cropping dari masing-masing citra yang dihasilkan untuk dilakukan identifikasi perbedaan antara citra asli dengan citra cropping yang dihasilkan serta penentuan objek dari masing-masing gambar yang telah diproses (citra asli dan citra cropping).

Digital teknologi yang berbasis suhu panas (thermal imaging) dan konsep refleksi (smart phone camera), dapat digunakan untuk mendeteksi telur ayam. Alat ini digunakan untuk proses pencitraan sebelum preprocessing sampai dengan pengujian citra. Dan akan dilakukan pebandingan citra asli dan citra cropping dari masing-masing gambar yang dihasilkan dari ke-2 alat tersebut. Dalam image processing, metode yang akan digunakan adalah thresholding, konversi citra RGB ke Grayscale maupun BW dan region props untuk menentukan objek telurnya.

\section{PUSTAKA}

\section{A. Penelitian Terkait}

Penelitian terdahulu menjadikan referensi untuk memberikan acuan perbedaan mengenai penelitian yang akan dilakukan. Kajian penelitian terdahulu dapat dilihat pada Tabel I.

TABEL I.

PERBANDINGAN PENELITI TERDAHULU DAN PENELITIAN YANG AKAN DILAKUKAN

\begin{tabular}{|c|c|c|c|c|c|}
\hline Peneliti & Citra & Objek & Faktor & Metode & Hasil \\
\hline $\begin{array}{l}\text { Utami } \\
(2009)\end{array}$ & $\begin{array}{l}\text { Gambar } \\
\text { Citra dari } \\
\text { Kamera } \\
\text { digital biasa }\end{array}$ & $\begin{array}{l}\text { Telur ayam } \\
\text { negeri, telur } \\
\text { ayam } \\
\text { kampung, } \\
\text { dan telur } \\
\text { bebek }\end{array}$ & $\begin{array}{l}\text { Karakteristi } \\
\text { k wama }\end{array}$ & $\begin{array}{l}\text { Ekstraksi ciri berdasar } \\
\text { citra HSV, dan minimum } \\
\text { distance classifier }\end{array}$ & $\begin{array}{l}\text { Hasilnya telur bebek memiliki Hue antara } \\
0,089-0,094 \text { dan saturasi antara } 0,12-0,32, \\
\text { telur ayam negeri memiliki Hue antara } \\
0,033-0,068 \text { dan saturasi antara } 0,52-0,62, \\
\text { dan telur ayam kampung memiliki Hue } \\
\text { antara } 0,061-0,068 \text { dan saturasi antara } 0,21- \\
0,25, \text { serta metode minimum distance } \\
\text { classifier mampu membedakan jenis telur } \\
\text { berdasarkan karakteristik warna citra[4] }\end{array}$ \\
\hline $\begin{array}{l}\text { Wijaya dan } \\
\text { Prayudi } \\
(2010)\end{array}$ & $\begin{array}{l}\text { Gambar } \\
\text { Citra dari } \\
\text { Kamera } \\
\text { digital biasa }\end{array}$ & $\begin{array}{l}\text { Telur Ayam } \\
\text { Ras }\end{array}$ & $\begin{array}{l}\text { Warna fisik } \\
\text { telur }\end{array}$ & $\begin{array}{l}\text { Computer vision bidang } \\
\text { segmentasi, dan regresi } \\
\text { linier }\end{array}$ & $\begin{array}{l}\text { Pengujian klasifikasi telur ayam ras ( } 36 \\
\text { sampel) diperoleh } 100 \% \text { tingkat keakuratan } \\
\text { dan prediksi bobot telur diperoleh } 42 \%[5]\end{array}$ \\
\hline $\begin{array}{l}\text { L. Liu dan } \\
\text { M. O. Ngadi } \\
(2012)\end{array}$ & $\begin{array}{l}\text { Gambar } \\
\text { Citra } \\
\text { menggunak } \\
\text { an Infrared } \\
\text { hyperspectr } \\
\text { al imaging }\end{array}$ & Telur ayam & $\begin{array}{l}\text { Embrio } \\
\text { pada telur }\end{array}$ & $\begin{array}{l}\text { Gabor filter, ROI, dan } K \text { - } \\
\text { Means Clustering }\end{array}$ & $\begin{array}{l}\text { Data embrio pada hari ke- } 0 \text { sebesar } 100 \% \text {, } \\
\text { hari ke- } 1 \text { sebesar } 78,8 \% \text {, hari ke- } 2 \text { sebesar } \\
74,1 \% \text {, hari ke- } 3 \text { sebesar } 81,8 \% \text {, dan hari } \\
\text { ke- } 4 \text { sebesar } 84,1 \% \text { dari tingkat } \\
\text { keakuratan[6] }\end{array}$ \\
\hline $\begin{array}{l}\text { Chern- } \\
\text { Sheng Lin, } \\
\text { dkk (2012) }\end{array}$ & $\begin{array}{l}\text { Gambar } \\
\text { Citra dari } \\
\text { Kamera } \\
\text { thermal } \\
\text { imaging }\end{array}$ & telur & $\begin{array}{l}\text { suhu telur, } \\
\text { dan embrio }\end{array}$ & $\begin{array}{l}\text { Operator sobel, teori } \\
\text { fuzzy, thresholding dan } \\
\text { Gray level co-occurrence } \\
\text { matrix (GLCM) }\end{array}$ & $\begin{array}{l}\text { Didapatkan keakuratan sistem sebesar } 96 \% \\
\text { akurat dengan kecepatan } 2-3 \text { s untuk } \\
\text { sampel } 36 \text { telur[7] }\end{array}$ \\
\hline $\begin{array}{l}\text { Khabibulloh } \\
\text {, dkk }(2012)\end{array}$ & $\begin{array}{l}\text { Gambar } \\
\text { Citra dari } \\
\text { Kamera } \\
\text { digital biasa }\end{array}$ & $\begin{array}{l}\text { Telur } \\
\text { Unggas }\end{array}$ & $\begin{array}{l}\text { Embrio } \\
\text { dalam telur }\end{array}$ & $\begin{array}{l}\text { Thresholding dan } \\
\text { perhitungan jumlah pixel, } \\
\text { serta memerlukan } \\
\text { peralatan untuk } \\
\text { memberikan cahaya pada } \\
\text { telur (dengan laser) }\end{array}$ & $\begin{array}{l}\text { Hasil yang diperoleh dalam pendekteksian } \\
\text { embrio yaitu: telur berembrio } 100 \% \text { tingkat } \\
\text { keberhasilan, telur rusak diperoleh } 91,7 \% \\
\text { berhasil dan } 8,3 \% \text { error, telur bagus } \\
\text { diperoleh } 100 \% \text { tingkat keberhasilan. } \\
\text { Sehingga secara keseluruhan diperoleh } \\
\text { persentase } 98,2 \% \text { berhasil dan } 1,8 \% \\
\text { error[8] }\end{array}$ \\
\hline $\begin{array}{l}\text { Ruslianto } \\
\text { (2013) }\end{array}$ & $\begin{array}{l}\text { Gambar } \\
\text { Citra dari } \\
\text { Kamera } \\
\text { digital biasa }\end{array}$ & $\begin{array}{l}\text { Telur ayam } \\
\text { dan Telur } \\
\text { burung } \\
\text { puyuh }\end{array}$ & $\begin{array}{l}\text { Ukuran fisik } \\
\text { telur }\end{array}$ & $\begin{array}{l}\text { Segmentasi dan connected } \\
\text { component analysis }\end{array}$ & $\begin{array}{l}10 \text { data citra yang diproses dapat } \\
\text { mengelompokan dan mengetahui jumlah } \\
\text { dari telur ayam dan telur burung puyuh } \\
\text { dengan tingkat keberhasilan } 100 \%[9]\end{array}$ \\
\hline $\begin{array}{l}\text { Triningtyas } \\
\text { dan } \\
\text { Maimunah }\end{array}$ & $\begin{array}{l}\text { Gambar } \\
\text { Citra dari } \\
\text { Kamera }\end{array}$ & $\begin{array}{l}\text { Telur Ayam } \\
\text { Ras }\end{array}$ & $\begin{array}{l}\text { Kebersihan } \\
\text { Kerabang } \\
\text { Telur }\end{array}$ & $\begin{array}{l}\text { Ekstraksi Ciri dengan } \\
\text { Statistik Orde Pertama } \\
\text { dan Statistik Orde ke-2, }\end{array}$ & $\begin{array}{l}\text { Klasifikasi telur ayam ras dengan } \\
\text { keakuratan } 0,8889 \text { dan error sebesar } 0,1111 \\
\text { dengan parameter } \mathrm{K}=3[10]\end{array}$ \\
\hline
\end{tabular}




\begin{tabular}{|c|c|c|c|c|c|}
\hline Peneliti & Citra & Objek & Faktor & Metode & Hasil \\
\hline (2015) & digital biasa & & & $\begin{array}{l}\text { dan } K \text {-Nearest } \\
\text { Neighbor(KNN) }\end{array}$ & \\
\hline $\begin{array}{l}\text { Nurhayati } \\
\text { (2015) }\end{array}$ & $\begin{array}{l}\text { Gambar } \\
\text { Citra dari } \\
\text { Kamera } \\
\text { digital biasa }\end{array}$ & $\begin{array}{l}2 \\
\text { Telur ayam } \\
\text { biasa dan } \\
\text { telur ayam } \\
\text { omega-3 }\end{array}$ & tekstur telur & $\begin{array}{l}\text { Ekualisasi histogram, } \\
\text { filter gaussian, } \\
\text { thresholding otsu } \\
\text { (segmentasi), dan } \\
\text { ekstraksi ciri dengan } \\
\text { statistik orde pertama }\end{array}$ & $\begin{array}{l}\text { Thresholding otsu mampu memisahkan } \\
\text { objek dan latar belakang, filter gaussian } \\
\text { menghilangkan noise (bintik-bintik) pada } \\
\text { citra, statistik orde pertama dapat } \\
\text { menganalisis dalam membedakan jenis } \\
\text { telur ayam biasa dan omega-3[11] }\end{array}$ \\
\hline $\begin{array}{l}\text { Liu Hai- } \\
\text { ling, dkk } \\
(2016)\end{array}$ & $\begin{array}{l}\text { Gambar } \\
\text { Citra dari } \\
\text { Kamera } \\
\text { thermal } \\
\text { imaging }\end{array}$ & Telur ayam & $\begin{array}{l}\text { Embrio } \\
\text { dalam telur, } \\
\text { dan suhu } \\
\text { yang } \\
\text { dipancarkan }\end{array}$ & $\begin{array}{l}\text { Cooling curve, cooling } \\
\text { area, region growing } \\
\text { segmentation, ellipse } \\
\text { fitting, Region of interest } \\
\text { (ROI), enhancement, dan } \\
\text { teori bayes }\end{array}$ & $\begin{array}{l}\text { Deteksi Telur tidak fertil dalam } 4 \text { hari } \\
\text { didapat } 89,6 \% \text { dari kenyataan, dan dalam } \\
16 \text { hari didapatkan embrio mati sebanyak } \\
96,3 \% \text { dari fakta yang terjadi[12] }\end{array}$ \\
\hline
\end{tabular}

TABEL I. LANJUTAN

PERBANDINGAN PENELITI TERDAHULU DAN PENELITIAN YANG AKAN DILAKUKAN

\begin{tabular}{|c|c|c|c|c|c|}
\hline Peneliti & Citra & Objek & Faktor & Metode & Hasil \\
\hline $\begin{array}{l}\text { Penelitian } \\
\text { yang akan } \\
\text { dilakukan } \\
\text { (sekarang) }\end{array}$ & $\begin{array}{l}\text { Gambar Citra } \\
\text { dari Kamera } \\
\text { thermal dan } \\
\text { kamera smart } \\
\text { phone }\end{array}$ & Telur ayam & $\begin{array}{l}\text { suhu telur, } \\
\text { embrio dan } \\
\text { fisik } \\
\text { (ukuran dan } \\
\text { bentuk) }\end{array}$ & $\begin{array}{l}\text { Ekualisasi histogram, } \\
\text { morfologi dilasi, } \\
\text { complement citra, region } \\
\text { props, centroid and } \\
\text { bounding box, clustering } \\
\text { dengan } K \text {-means }\end{array}$ & $\begin{array}{l}\text { Hasil yang diharapakan dapat } \\
\text { mengidentifikasi telur ayam secara tepat } \\
\text { dengan keakuratan } 100 \% \text {. Dan analisis } \\
\text { identifikasi telur dari hasil cropping. }\end{array}$ \\
\hline
\end{tabular}

\section{B. 3 itra}

Citra dapat diperoleh dari penangkapan kekuatan sinar yang dipantulkan objek. Sehingga citra merupakan 3 presentasi (gambaran), kemiripan, atau imitasi dari obyek. Citra merupakan output alat perekaman, seperti kamera yang be 10 at analog maupun digital dan juga bersifat thermal. Citra digital merupakan sebuah array dengan nilainilai real maupun komplek yang direpresentasikan deretan bit tertentu[13].

Citra digital atau analog berbeda dengan citra berbasis thermal, citra digital atau analog merupakan citra yang merupakan representasi/gambaran obyek nyata, sedangkan citra berbasis thermal merupakan citra hasil deteksi suhu yang dipancarkan oleh obyek yang ditangkap oleh kamera thermal, sehingga citra yang dihasilk3 berupa olahan pancaran panas obyek yang tertangkap dan menghasilkan warna-warna tertentu sesuai dengan panas yang dipancarkan

Pengolahan citra perlu dilakukan untuk :

a. Memperbaiki kualita13 ambar[13].

b. Melakukan proses deskripsi obyek atau pengenalan obyek pada citra.

c. Melakukan kompresi untuk tujuan penyimpanan data, transmisi data, dan waktu proses data.

29Proses pengolahan citra dengan menggunakan komputer dapat memberikan hasil yang lebih baik dari sebelumnya. Alur dari pengolahan citra yaitu :

11ra Asli Proses $\rightarrow$ Pengolahan Citra $\rightarrow$ Citra Hasil

Akuisisi citra m 7 pakan proses awal untuk mendapatkan citra. Tujuannya adalah untuk mendapatkan data yang diperlukan dan memilih metode perekaman citra. Proses ini dimulai dari persiapan obyek yang akan diambil gambarnya, alat-alat, dan proses pencitraannya. Pencitraan merupakan kegiatan transformasi dari citra tampak (misal: foto, gambar, lukisan) menjadi citra.

\section{Preprocessing}

Preprocessing diperlukan untuk menjamin kelancaran pada proses berikutnya, yaitu antara lain dengan [14]:

a. 11. ingkatan kualitas citra[13] (kontras/kecerahan)

b. Menghilangkan noise

c. Image restoration

d. Image transformation

e. Menentukan bagian citra yang akan 28 servasi

Dalam proses preprocessing dapat dilakukan dengan beberapa metode salah satunya adalah menggunakan citra grayscale. Citra grayscale merupakan citra dengan menggunakan warna abu-abu. Nilai intensitas untuk tiap piksel p3a citra grayscale merupakan nilai tunggal dengan interval $0-255$, sedangkan citra berwarna (RGB) perlu tiga nilai intensitas yang berada pada interval $0-255$ tiap pikselnya. Citra grayscale semakin mendekati nilai 255 , maka semakin terang.

Citra warna $9 \mathrm{~GB})$ diubah menjadi citra grayscale digunakan untuk merat 15 nilai piksel dari 3 nilai RGB menjadi 1 nilai. Tetapi karena ketiga warna pokok tersebut dianggap tidak seragam dalam hal kemampuan kontribusi pada kecerahan, maka untuk mengubah citra warna (RGB) 10 jadi citra grayscale dapat menggunakan persamaan: $\mathrm{Y}=$ $0.299 \mathrm{R}+0.587 \mathrm{G}+0.114 \mathrm{~B}$, dimana $\mathrm{Y}$ adalah nilai kecerahan guatu piksel pada citra abu-abu, dengan persentasi $29,9 \%$ dari warna merah (R), 58,7\% dari warna hijau (G), dan $11,4 \%$ dari warna biru (B). 


\section{Histogram}

Histogram merupakan probabilitas statistik distribusi pada setiap tingkat abu-abu (grayscale) dalam citra digital[15]. Dengan histogram ekualisasi dapat dilakukan perataan histogram p 6 la citra, sehingga citra dapat dikelompokkan sesuai level nilai intensitas warna piksel yang berbeda. Pada citra grayscale 8 bit, intensitasnya ada 256 level nilai yang berbeda. Sehingga histogram akan menampilkan grafik secara terdistribusi dari 256 level nilai pixel. Jadi untuk mendapatkan hasil histogram yang rata maka citra harus citra grayscale.

\section{E. Morfologi}

Morfologi merupakan teknik pengolahan citra yang mengacu pada bentuk segmen atau region[13]. Morfologi dalam penelitian ini terdapat beberapa operasi digunakan yaitu diantaranya:

a. Operasi dilasi bertujuan untuk memperbesar ukuran segmen pada lapisan di sekitar obyek.

b. Operasi opening merupakan kombinasi proses yaitu proses erosi kemudian dilasi. Operasi ini bertujuan untuk memperhalus batas obyek, memisahkan obyek dan menghilangkan derau.

c. Operasi erosi yaitu proses yang menghasilkan ukuran citra lebih kecil (kebalikan dari operasi dilasi).

\section{F. Segmentasi}

Segmentasi citra dilakukan untuk memisahkan obyek dan latar belakang[14]. Proses pemisahan bertujuan untuk memudahkan proses klasifikasi dan penghitungan dengan tepat akurat.

\section{1) Thresholding}

Operasi binerisasi yaitu proses segmentasi dari sebuah citra grayscale dengan menghasilkan citra biner. Proses binerisasi ini 2 memerlukan sebuah nilai threshold (T). Thresholding OTSU merupakan algoritma yang digunakan untuk melakukan segmentasi citra digital abu-abu ke dalam citra digital hitam (foreground) dan putih (background). Histogram dari citra yang 8 udah diproses dengan thresholding otsu menunjukkan sebaran nilai intensitas dari tiap piksel pada citra dalam 1 dimensi. Fungsi histogram ini adalah memudahkan dalam pengelompokkan piksel-piksel dalam citra. Pengelompokkan didasarkan pada nilai threshold. Jadi, metode Otsu dikatakan optimal jika nilai threshold mampu memisahkan kelas-kelas sehingga piksel antara kelas memiliki nilai intensitas yang berbeda.

\section{2) Pelabelan}

Pelabelan dilakukan jika terdapat lebih dari satu obyek yang akan dianalisis. Proses dilakukan dengan mencari komponen terkoneksi dalam suatu citra. Komponen terkoneksi adalah bagian yang mewakili sebuah obyek dalam citra dengan obyek lebih dari satu. Operasi pelabelan dapat memudahkan operasi penghitungan pada objek-objek. Tanpa pelabelan, perhitungan ciri-ciri dari obyek akan rancu sebab hasil yang didapat merupakan gabungan dari semua
20

obyek yang ada. Pelabelan bertujuan untuk membedakan antara obyek yang satu dengan obyek yang lain sehingga jika terdapat noise yang cukup besar untuk dihapus atau dihilangkan dapat dengan mudah dilakukan karena masingmasing obyek telah diberi label.

\section{G. Region props dan Bounding box}

Region props digunakan untuk mengukur sekumpulan properti dari setiap region dari matrik citra. Perpaduan dengan centroid dan bounding box dapat menentukan titiktitik centroid dan bounding box. Centroid adalah nilai tengah dari obyek yang terdeteksi, sedangkan bounding box merupakan fungsi yang digunakan untuk membuat kotak yang sesuai besarnya dengan obyek yang teridentifikasi[16]. Dan untuk membantu dalam proses penentuan centroid dan bounding box diperlukan proses regionprops.

\section{H. Cropping}

Cropping merupakan suatu proses untuk memperkecil ukuran citra dengan memotong citra pada koordinat tertentu pada area citra[17]. Sehingga proses cropping akan memotong sebagian objek pada bidang gambar untuk mendapatkan bagian dari gambar tertentu dengan ukuran tertentu.

\section{METODE PENELITIAN}

Metode Penelitian merupakan cara, prosedur atat langkah-langkah dalam mendapatkan pengetahuan ilmiah. Sehingga dalam melakukan penelitian berdasar pada pendekatan ilmiah yang dapat dipertanggungjawabkan. Metode yang digunakan harus jelas, ada tata cara dan prosedur yang objektif dan b25 [18]. Dalam penelitian ini metodologi yang digunakan dapat dilihat pada gambar 1 . Penelitian ini dilakukan untuk membandingkan analisis proses preprocessing yang dilakukan, baik histogram maupun konversi citra menjadi grayscale dan hitam putih, serta perhitungan centroid and bounding box dan jumlah objek. Objek yang digunakan adalah telur ayam dengan tujuan untuk melakukan identifikasi bahwa ukuran telur ayam jika dilakukan cropping akan memiliki ukuran yang berbeda.

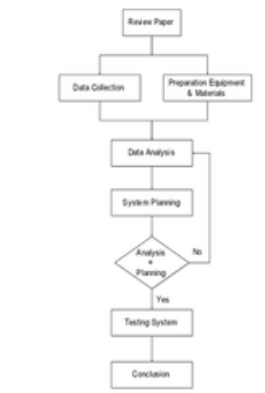

Gambar 1. Metode Penelitian[19]

Perancangan sistem yang digunakan dalam pengolahan citra telur ayam ditunjukkan pada gambar 2 . 


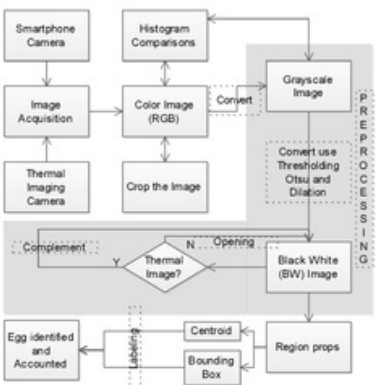

Gambar 2. Langkah-langkah Pengolahan Citra untuk Identifikasi Telur

Gambar 2 menunjukan langkah-langkah pengolahan citra mulai dari awal pengambilan gambar dengan kamera thermal dan kamera smart phone sampai pada proses identifikasi dan perhitungan objeknya. Pada proses preprocessing dilakukan dengan pengubahan citra warna (RGB) menjadi Grayscale, kemudian diubah menjadi citra Black White (BW). Sebelum melakukan proses identifikasi dan perhitungan objek telur ayam, pada preprocessing dilakukan pemisahan proses jika gambar yang akan diproses adalah citra thermal maka perlu dikomplemen terlebih dahulu yaitu dilakukan proses pengubahan nilai pixel 1 menjadi 0 dan 0 menjadi 1 sehingga citra akan tetap menjadi citra Black White (BW). Jika gambar bukan citra thermal maka gambar tidak perlu dikomplemen tapi dilakukan proses opening dan gambar tetap citra Black White. Setelah preprocessing maka dilakukan proses region props yang akan memberikan hasil untuk menentukan centoid dan boundix box sehingga akan dapat mengidentifikasi dan menghitung jumlah telur yang diproses.

\section{PEMBAHASAN}

\section{A. Perbandingan Ukuran Citra Telur Asli dengan Citral Hasil Croping}

Gambar citra asli dan hasil cropping terlihat pada Tabel II Dimana setiap proses cropping yang dilakukan akan memberikan ukuran yang berbeda termasuk dengan objek yang memiliki jumlah yang sama. Sehingga cropping dilakukan untuk mengecilkan ukuran gambar dengan memotong gambar menjadi lebih kecil.

TABEL II.

UKURAN CITRA ASLI DAN HASIL CROPPING DENGAN OBJEK

\begin{tabular}{|l|c|c|c|c|c||}
\hline Citra & $\begin{array}{c}\text { Nam } \\
\text { a }\end{array}$ & $\begin{array}{c}\text { Kamera } \\
\text { Therma } \\
\text { I (a) }\end{array}$ & $\begin{array}{c}\text { Size } \\
\text { (a) }\end{array}$ & $\begin{array}{c}\text { Kamera } \\
\text { Smart- } \\
\text { phone } \\
\text { (b) }\end{array}$ & \multicolumn{1}{|c|}{$\begin{array}{c}\text { Size } \\
\text { (b) }\end{array}$} \\
\hline $\begin{array}{l}\text { Citra } \\
\text { Asli }\end{array}$ & Fg1.1 & 88 & $\begin{array}{l}480 \mathrm{X} \\
640 \\
\text { (Pixels) } \\
900 \mathrm{~KB}\end{array}$ & 890 & $\begin{array}{l}960 \mathrm{X} \\
1280 \\
\text { (Pixels) } \\
125 \mathrm{~KB}\end{array}$ \\
\hline
\end{tabular}

\begin{tabular}{|c|c|c|c|c|c|}
\hline Citra & $\begin{array}{c}\text { Nam } \\
\text { a }\end{array}$ & $\begin{array}{c}\text { Kamera } \\
\text { Therma } \\
\text { I (a) }\end{array}$ & $\begin{array}{l}\text { Size } \\
\text { (a) }\end{array}$ & $\begin{array}{l}\text { Kamera } \\
\text { Smart- } \\
\text { phone } \\
\text { (b) }\end{array}$ & $\begin{array}{l}\text { Size } \\
\text { (b) }\end{array}$ \\
\hline $\begin{array}{l}\text { Citra } \\
\text { Hasil } \\
\text { Cropin } \\
\text { g } \\
\text { (Semua } \\
\text { Objek) } \\
\end{array}$ & $\mathrm{Fgl} .2$ & & $\begin{array}{l}325 \mathrm{X} \\
413 \\
\text { (pixels) } \\
393 \mathrm{~KB}\end{array}$ & & $\begin{array}{l}747 \mathrm{X} \\
1113 \\
\text { (pixels) } \\
155 \mathrm{~KB}\end{array}$ \\
\hline \multirow{2}{*}{$\begin{array}{l}\text { Citra } \\
\text { Hasil } \\
\text { Croppi } \\
\text { ng } \\
(4 \\
\text { Objek) }\end{array}$} & $\begin{array}{l}\mathrm{Fg} 1.3 \\
-1\end{array}$ & & $\begin{array}{l}256 \mathrm{X} \\
304 \\
\text { (pixels) } \\
228 \mathrm{~KB}\end{array}$ & & $\begin{array}{l}709 \times 791 \\
\text { (pixels) } \\
101 \mathrm{~KB}\end{array}$ \\
\hline & $\begin{array}{l}\mathrm{Fg} 1.3 \\
-2\end{array}$ & & $\begin{array}{l}290 \mathrm{X} \\
259 \\
\text { (pixels) } \\
220 \mathrm{~KB}\end{array}$ & & $\begin{array}{l}779 \times 649 \\
\text { (pixels) } \\
93.1 \mathrm{~KB}\end{array}$ \\
\hline \multirow{2}{*}{$\begin{array}{l}\text { Citra } \\
\text { Hasil } \\
\text { Croppi } \\
\text { ng } \\
(3 \\
\text { Objek) }\end{array}$} & $\begin{array}{l}\mathrm{Fg} 1.4 \\
-1\end{array}$ & & $\begin{array}{l}170 \mathrm{X} \\
416 \\
\text { (pixels) } \\
207 \mathrm{~KB}\end{array}$ & & $\begin{array}{l}369 \mathrm{X} \\
1043 \\
\text { (pixels) } \\
76.5 \mathrm{~KB}\end{array}$ \\
\hline & $\begin{array}{l}\mathrm{Fg} 1.4 \\
-2\end{array}$ & & $\begin{array}{l}179 \mathrm{X} \\
403 \\
\text { (pixels) } \\
211 \mathrm{~KB}\end{array}$ & & $\begin{array}{l}413 \mathrm{X} \\
1125 \\
\text { (pixels) } \\
85.9 \mathrm{~KB}\end{array}$ \\
\hline \multirow{7}{*}{$\begin{array}{l}\text { Citra } \\
\text { Hasil } \\
\text { Croppi } \\
\text { ng } \\
(2 \\
\text { Objek) }\end{array}$} & $\begin{array}{l}\mathrm{Fg} 1.5 \\
-1\end{array}$ & & $\begin{array}{l}337 \mathrm{X} \\
157 \\
\text { (pixels) } \\
155 \mathrm{~KB}\end{array}$ & & $\begin{array}{l}729 \times 465 \\
\text { (pixels) } \\
66.3 \mathrm{~KB}\end{array}$ \\
\hline & $\begin{array}{l}\mathrm{Fg} 1.5 \\
-2\end{array}$ & & $\begin{array}{l}280 \mathrm{X} \\
134 \\
\text { (pixels) } \\
110 \mathrm{~KB}\end{array}$ & & $\begin{array}{l}745 \times 339 \\
\text { (pixels) } \\
44.1 \mathrm{~KB}\end{array}$ \\
\hline & $\begin{array}{l}\mathrm{Fg} 1.5 \\
-3\end{array}$ & & $\begin{array}{l}292 \mathrm{X} \\
160 \\
\text { (pixels) } \\
136 \mathrm{~KB}\end{array}$ & & $\begin{array}{l}733 \times 323 \\
\text { (pixels) } \\
47.2 \mathrm{~KB}\end{array}$ \\
\hline & $\begin{array}{l}\mathrm{Fg} 1.5 \\
-4\end{array}$ & & $\begin{array}{l}159 \mathrm{X} \\
303 \\
\text { (pixels) } \\
141 \mathrm{~KB}\end{array}$ & & $\begin{array}{l}335 \times 713 \\
\text { (pixels) } \\
44.7 \mathrm{~KB}\end{array}$ \\
\hline & $\begin{array}{l}\text { Fg1.5 } \\
-5\end{array}$ & & $\begin{array}{l}140 \mathrm{X} \\
295 \\
\text { (pixels) } \\
121 \mathrm{~KB} \\
\end{array}$ & & $\begin{array}{l}347 \times 637 \\
\text { (pixels) } \\
42.8 \mathrm{~KB}\end{array}$ \\
\hline & $\begin{array}{l}\text { Fg1.5 } \\
-6\end{array}$ & & $\begin{array}{l}152 \mathrm{X} \\
259 \\
\text { (pixels) } \\
115 \mathrm{~KB} \\
\end{array}$ & & $\begin{array}{l}381 \times 821 \\
\text { (pixels) } \\
56.4 \mathrm{~KB}\end{array}$ \\
\hline & $\begin{array}{l}\mathrm{Fg} 1.5 \\
-7\end{array}$ & & $\begin{array}{l}148 \mathrm{X} \\
244 \\
\text { (pixels) } \\
105 \mathrm{~KB}\end{array}$ & & $\begin{array}{l}401 \times 691 \\
\text { (pixels) } \\
50.6 \mathrm{~KB}\end{array}$ \\
\hline
\end{tabular}


Volume 2 Nomor 3 Desember 2016

TABEL III

UKURAN CITRA DAN HASIL CROPPING SETIAP OBJEK TELUR

\begin{tabular}{|c|c|c|c|c|c|}
\hline Citra & $\begin{array}{c}\text { Nam } \\
\mathbf{a}\end{array}$ & $\begin{array}{c}\text { Kamer } \\
\text { a } \\
\text { Therm } \\
\text { al (a) }\end{array}$ & $\begin{array}{l}\text { Size } \\
\text { (a) }\end{array}$ & $\begin{array}{c}\text { Kamera } \\
\text { Smart } \\
\text { phone } \\
\text { (b) }\end{array}$ & $\begin{array}{c}\text { Size } \\
\text { (b) }\end{array}$ \\
\hline $\begin{array}{l}\text { Citra } \\
\text { Asli }\end{array}$ & $\begin{array}{l}\mathrm{Fg} 2 . \\
1\end{array}$ & 8 & $\begin{array}{l}480 \mathrm{X} \\
640 \\
\text { (Pixels) } \\
900 \mathrm{~KB}\end{array}$ & & $\begin{array}{l}960 \mathrm{X} \\
1280 \\
\text { (Pixels) } \\
125 \mathrm{~KB}\end{array}$ \\
\hline \multirow{6}{*}{$\begin{array}{l}\text { Citra } \\
\text { Hasil } \\
\text { Cropin } \\
\mathrm{g} \\
\text { (1 } \\
\text { Objek) }\end{array}$} & $\begin{array}{l}\mathrm{Fg} 2 \text {. } \\
2\end{array}$ & & $\begin{array}{l}145 \mathrm{X} \\
106 \\
\text { (pixels) } \\
45.3 \mathrm{~KB}\end{array}$ & & $\begin{array}{l}335 \times 327 \\
\text { (pixels) } \\
20.6 \mathrm{~KB}\end{array}$ \\
\hline & $\begin{array}{l}\mathrm{Fg} 2 . \\
3\end{array}$ & & $\begin{array}{l}125 \mathrm{X} \\
133 \\
\text { (pixels) } \\
48.8 \mathrm{~KB}\end{array}$ & & $\begin{array}{l}313 \times 289 \\
\text { (pixels) } \\
16.4 \mathrm{~KB}\end{array}$ \\
\hline & $\begin{array}{l}\mathrm{Fg} 2 . \\
4\end{array}$ & & $\begin{array}{l}130 \mathrm{X} \\
120 \\
\text { (pixels) } \\
45.7 \mathrm{~KB}\end{array}$ & & $\begin{array}{l}335 \times 327 \\
\text { (pixels) } \\
22.3 \mathrm{~KB}\end{array}$ \\
\hline & $\begin{array}{l}\mathrm{Fg} 2 . \\
5\end{array}$ & & $\begin{array}{l}126 \mathrm{X} \\
111 \\
\text { (pixels) } \\
41.3 \mathrm{~KB}\end{array}$ & & $\begin{array}{l}379 \times 348 \\
\text { (pixels) } \\
23,9 \mathrm{~KB}\end{array}$ \\
\hline & $\begin{array}{l}\mathrm{Fg} 2 . \\
6\end{array}$ & & $\begin{array}{l}137 \mathrm{X} \\
118 \\
\text { (pixels) } \\
47.6 \mathrm{~KB}\end{array}$ & & $\begin{array}{l}377 \times 345 \\
\text { (pixels) } \\
21.6 \mathrm{~KB}\end{array}$ \\
\hline & $\begin{array}{l}\mathrm{Fg} 2 \text {. } \\
7\end{array}$ & & $\begin{array}{l}138 \mathrm{X} \\
114 \\
\text { (pixels) } \\
45.8 \mathrm{~KB}\end{array}$ & & $\begin{array}{l}385 \times 333 \\
\text { (pixels) } \\
25.3 \mathrm{~KB}\end{array}$ \\
\hline
\end{tabular}

\begin{tabular}{|c|c|c|c|c|c|}
\hline $\begin{array}{c}\mathrm{N} \\
\mathbf{o}\end{array}$ & $\begin{array}{c}\text { Citra } \\
\text { Warn } \\
\text { a }\end{array}$ & $\begin{array}{c}\text { Histogra } \\
\text { m Warna } \\
\text { (RGB) }\end{array}$ & $\begin{array}{l}\text { Histogra } \\
\text { m Warna }\end{array}$ & $\begin{array}{c}\text { Citra } \\
\text { Grayscal } \\
\text { e }\end{array}$ & $\begin{array}{c}\text { Histogra } \\
\text { m } \\
\text { Grayscal } \\
\text { e }\end{array}$ \\
\hline 3 & & & & & \\
\hline 4 & & & & & \\
\hline
\end{tabular}

Berdasarkan Tabel IV didapatkan perbedaan setiap pengolahan histogram pada setiap sampel hasil cropping. Pada setiap gambar pada Tabel IV menunjukan bagian dari citra aslinya. Dari sampel pada citra warna didapatkan histogram yang berbeda karena yang dibuat histogram adalah setiap komponen Red, Green, dan Blue pada setiap citra yang diolah. Sehingga karena setiap komponen yang didapatkan memiliki perbedaan maka menghasilkan histogram yang berbeda pula. Begitu pula dengan histogram dari citra grayscale, citra grayscale memiliki range antara 0255. Jika pada setiap gambar didapati warna dengan range tertentu (misalkan: 124) dengan jumlah kemunculan yang berbeda maka akan didapatkan gambar histogram yang berbeda. Jadi dapat diketahui bahwa setiap hasil cropping dari setiap gambar dan hasil cropping itu bukan merupakan citra aslinya maka akan mendapatkan gambar histogram yang berbeda, baik untuk citra warna maupun citra grayscale.

2) Digital Image dengan Citra Asli dan Beberapa Sampel dari Hasil Cropping

TABEL $\mathrm{V}$.

Pada Tabel III menunjukkan hasil cropping dari gambar yang terdiri dari kelompok objek telur menjadi 1 objek telur yang akan dilakukan identifikasi dengan masing-masing ukuran yang berbeda-beda.

B. Analisis Hostogram Citra Warna/Asli dan Citra

Grayscale dengan Hasil Cropping

1) Thermal Image dengan Citra Asli dan Beberapa Sampel dari Hasil Cropping

TABEL IV.

HISTOGRAM WARNA PADA CITRA ASLI DAN BEBERAPA SAMPEL DARI HASIL CROPPING

\begin{tabular}{|c|c|c|c|c|c|}
\hline $\begin{array}{c}\mathbf{N} \\
\mathbf{o}\end{array}$ & $\begin{array}{c}\text { Citra } \\
\text { Warn } \\
\mathbf{a}\end{array}$ & $\begin{array}{c}\text { Histogra } \\
\mathbf{m} \text { Warna } \\
\text { (RGB) }\end{array}$ & $\begin{array}{c}\text { Histogra } \\
\mathbf{m} \text { Warna }\end{array}$ & $\begin{array}{c}\text { Citra } \\
\text { Grayscal } \\
\mathbf{e}\end{array}$ & $\begin{array}{c}\text { Histogra } \\
\mathbf{m} \\
\text { Grayscal } \\
\mathbf{e}\end{array}$ \\
\hline 1 & 88 & & & & \\
\hline 2 & & & & & \\
\hline
\end{tabular}

HISTOGRAM WARNA PADA CITRA ASLI DAN BEBERAPA SAMPEL DARI HASIL CROPPING

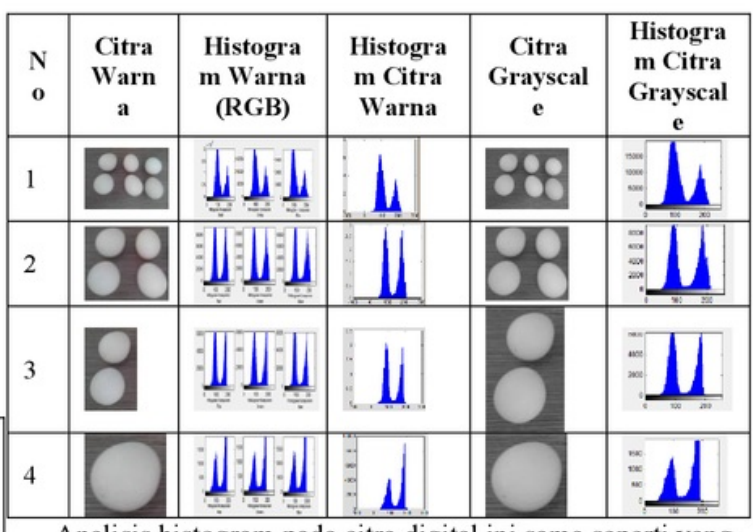

Analisis histogram pada citra digital ini sama seperti yang dilakukan pada thermal image, baik pada citra warna maupun citra grayscale. Sehingga diperoleh bahwa untuk histogram pada citra digital mempunyai analisis yang sama dengan citra dari thermal image hanya yang membedakan adalah citra yang diproses dan proses pencitraannya. Citra digital dilakukan proses pencitraan menggunakan smart 
phone camera yang mempunyai konsep refleksi gambar yaitu gambar yang dihasilkan adalah gambar yang sama atau mirip dengan objek yang terlihat. Sedangkan thermal image merupakan representasi dari flir camera yang berbasis thermal yaitu kamera menangkap suhu/panas yang direpresentasikan dalam sebuah gambar dengan kombinasi warna tertentu yang menunjukan suhu/panas dari objek yang diambil gambarnya.

\section{Proses Citra Hasil dari Convert ke Grayscale}

Pengubahan citra dari citra warna (RGB) menjadi citra Grayscale dapat dilihat pada Tabel IV dan Tabel V. Kemudian dilakukan proses dengan menggunakan thresholding otsu dan proses dilasi untuk masing-masing citra. Proses dilasi dilakuan dengan menggunakan strel "diamond" dengan ukuran 7x7.

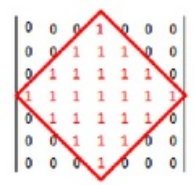

Gambar 3. Matriks Diamond 7×7 untuk Proses Dilasi

Pada gambar 3 terlihat bahwa matrik untuk proses dilasi berbentuk diamond. Sehingga ketika diimplementasikan pada citra telur maka pada citra graysca 24 akan terjadi penambahan area berbentuk diamond seperti pada gambar 4 .

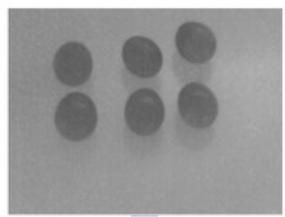

(a)

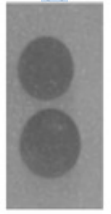

(c)

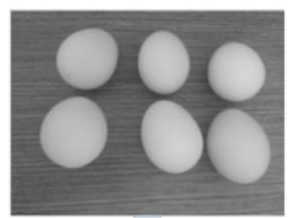

(b)

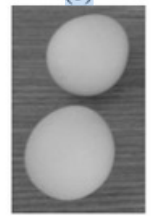

(d)
Gambar 4. Hasil Proses Dilasi pada (a) Gambar dari Thermal (Original),

(b) Gambar dari Smart phone (Original), (c) Cropping dari a, (d) Cropping dari $b$.

Gambar 4 menunjukkan hasil proses dilasi pada citra grayscale untuk sampel citra asli dan cropping baik dari kamera thermal maupun kamera smart phone.

D. Convert Citra Grayscale Menjadi Citra Hitam Putih $(B W)$

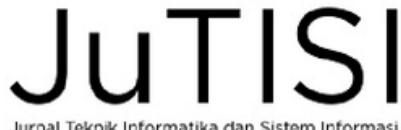

Pengubahan citra grayscale dari hasil proses dilasi menjadi citra hitam putih (BW). Citra dari kamera thermal perlu dilakukan proses komplemen untuk bisa dilakukan region props dan menghitungan objek dengan centroid dan bounding box karena yang akan diidentifikasi adalah citra dengan nilai pixel 1. Terlihat pada gambar 5.(a) menunjukan bahwa objek telur bernilai 0 (hitam). Jadi perlu dilakukan komplemen yaitu mengubah nilai 0 menjadil dan 1 menjadi 0 (gambar 5.(a) diubah menjadi gambar 5.(b)). Sedangkan untuk citra dari kamera smart phone perlu dilakukan proses opening untuk menghilangkan derau/noise seperti pada gambar 6. (a) diubah menjadi 6.(b).

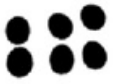

(a)

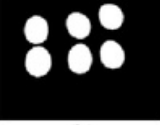

(b)
Gambar 5. Konversi Gambar dari Kamera Thermal

(a) Citra Black White, (b) Komplemen dari Citra BW

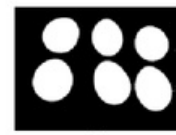

(a)

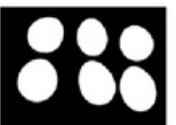

(b)
Gambar 6. Konversi Gambar dari Kamera Smart phone

(a) Citra Black White Image, (b) Proses Opening dari Citra BW

Setiap sampel dilakukan proses yang sama untuk dilakukan identifikasi, termasuk pada pada konversi citra grayscale menjadi citra hitam putih. Pada tahap ini gambar yang telah diproses mampu menunjukan pemisahan objek dengan latar belakang sehingga objek dapat teridentifikasi dan dapat dihitung.

\section{E. Hasil Pelabelan dan Region Props dari Proses Pengolahan Citra}

Hasil pelabelan dan region props dari sample yang digunakan menghasilkan citra warna dari proses pelabelan dan terdapat titik centroid dan bounding box serta lua $23 \mathrm{ea}$ yang dihasilkan. Hasil pelabelan dan region props dapat dilihat pada gambar 7 .

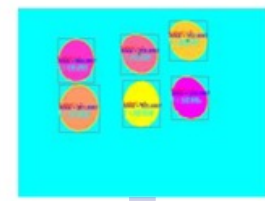

(a)

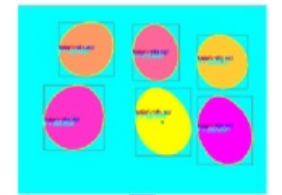

(b)
Gambar 7. Hasil Pelabelan dan Region props pada Citra Telur Ayam Asli dari (a) Image of Thermal (b) Image of Camera Smart phone

Dari gambar 7 maka akan didapatkan Tabel VI yang terdiri dari nilai titik centroid di $\mathrm{x}$ dan $\mathrm{y}$, dan luas area dari masing-masing objek pada tiap gambar. 
TABEL VI. A

HASIL CENTROID DAN BOUNDING BOX SERTA LUAS AREA DARI SEMUA SAMPEL DARI KAMERA THERMAL

\begin{tabular}{|c|c|c|c|c|c|}
\hline \multirow[b]{2}{*}{ No } & \multirow[b]{2}{*}{ Nama } & \multirow[b]{2}{*}{ Jml } & \multicolumn{3}{|c|}{ Citra dari Thermal } \\
\hline & & & $\begin{array}{c}\text { Centroid } \\
\mathrm{X}\end{array}$ & $\begin{array}{c}\text { Centroid } \\
\text { Y }\end{array}$ & $\begin{array}{c}\text { Area } \\
\text { (pixels) }\end{array}$ \\
\hline 1.1 & \multirow{6}{*}{ Fgl.1 } & \multirow{6}{*}{6} & 150.3861 & 131.9312 & 904.0007 \\
\hline 1.2 & & & 157.4644 & 252.8494 & 911.0007 \\
\hline 1.3 & & & 311.1539 & 114.8167 & 918.0007 \\
\hline 1.4 & & & 316.6732 & 242.5348 & 925.0007 \\
\hline 1.5 & & & 435.1202 & 80.8753 & 932.0007 \\
\hline 1.6 & & & 439.6460 & 226.9189 & 939.0007 \\
\hline 2.1 & \multirow{6}{*}{ Fgl 1.2} & \multirow{6}{*}{6} & 59.4943 & 123.1179 & 904.0013 \\
\hline 2.2 & & & 66.6350 & 244.6218 & 911.0013 \\
\hline 2.3 & & & 220.3154 & 106.4071 & 918.0013 \\
\hline 2.4 & & & 225.9330 & 234.1674 & 925.0013 \\
\hline 2.5 & & & 344.0460 & 72.7743 & 932.0013 \\
\hline 2.6 & & & 348.7343 & 218.5409 & 939.0013 \\
\hline 3.1 & $\begin{array}{l}\text { Fg1.3- } \\
1\end{array}$ & \multirow{4}{*}{4} & 75.5304 & 75.0826 & 900.002 \\
\hline 3.1 & & & 82.6829 & 196.6650 & 907.002 \\
\hline 3.1 & & & 236.3398 & 58.3843 & 914.002 \\
\hline 3.1 & & & 241.9058 & 186.0712 & 921.002 \\
\hline 4.1 & \multirow{4}{*}{$\begin{array}{l}\text { Fgl.3- } \\
2\end{array}$} & \multirow{4}{*}{4} & 63.3519 & 89.5420 & 900.0026 \\
\hline 4.2 & & & 68.8392 & 217.3332 & 907.0026 \\
\hline 4.3 & & & 187.0555 & 55.8305 & 914.0026 \\
\hline 4.4 & & & 191.7318 & 201.7042 & 921.0026 \\
\hline 5.1 & \multirow{3}{*}{$\begin{array}{l}\text { Fgl.4- } \\
1\end{array}$} & \multirow{3}{*}{3} & 58.4943 & 111.1179 & 898.0032 \\
\hline 5.2 & & & 219.3114 & 94.3860 & 905.0032 \\
\hline 5.3 & & & 343.0460 & 60.7743 & 912.0032 \\
\hline 6.1 & $\begin{array}{l}\text { Fgl.4- } \\
2\end{array}$ & 3 & 60.6350 & 94.6218 & 898.0038 \\
\hline 6.2 & & & 219.9330 & 84.1674 & 905.0038 \\
\hline 6.3 & & & 342.7343 & 68.5409 & 912.0038 \\
\hline 7.1 & $\begin{array}{l}\text { Fg1.5- } \\
1\end{array}$ & 2 & 64.5304 & 107.0826 & 896.0044 \\
\hline 7.2 & & & 71.6854 & 228.5741 & 903.0044 \\
\hline 8.1 & $\begin{array}{l}\text { Fgl.5- } \\
2\end{array}$ & 2 & 67.3398 & 73.3843 & 896.005 \\
\hline 8.2 & & & 72.9058 & 201.0712 & 903.005 \\
\hline 9.1 & Fg1.5- & 2 & 67.0846 & 68.1301 & 896.0026 \\
\hline
\end{tabular}

\begin{tabular}{|c|c|c|c|c|c|}
\hline \multirow[b]{2}{*}{ No } & \multirow[b]{2}{*}{ Nama } & \multirow[b]{2}{*}{ Jml } & \multicolumn{3}{|c|}{ Citra dari Thermal } \\
\hline & & & $\begin{array}{c}\text { Centroid } \\
\mathrm{X}\end{array}$ & $\begin{array}{c}\text { Centroid } \\
\mathrm{Y}\end{array}$ & $\begin{array}{c}\text { Area } \\
\text { (pixels) }\end{array}$ \\
\hline & 3 & & & & \\
\hline 9.2 & & & 71.6118 & 214.3855 & 903.0026 \\
\hline 10.1 & $\begin{array}{l}\text { Fgl.5- } \\
4\end{array}$ & 2 & 86.5317 & 107.2514 & 896.0038 \\
\hline 10.2 & & & 247.3398 & 90.3843 & 903.0038 \\
\hline 11.1 & $\begin{array}{l}\text { Fgl.5- } \\
5\end{array}$ & 2 & 69.6854 & 72.5741 & 900.005 \\
\hline 11.2 & & & 228.9058 & 62.0712 & 921.005 \\
\hline 12.1 & $\begin{array}{l}\text { Fg1.5- } \\
6\end{array}$ & 2 & 60.3550 & 99.5776 & 896.0056 \\
\hline 12.2 & & & 184.0555 & 65.8305 & 903.0056 \\
\hline 13.1 & $\begin{array}{l}\text { Fgl.5- } \\
7\end{array}$ & 2 & 55.8392 & 80.3332 & 896.0068 \\
\hline 13.2 & & & 178.7318 & 64.7042 & 903.0038 \\
\hline 14.1 & & & 150.3861 & 131.9312 & 904.0007 \\
\hline 14.2 & & & 157.4644 & 252.8494 & 911.0007 \\
\hline 14.3 & & & 311.1539 & 114.8167 & 918.0007 \\
\hline 14.4 & $\mathrm{Fg} 2.1$ & 6 & 316.6732 & 242.5348 & 925.0007 \\
\hline 14.5 & & & 435.1202 & 80.8753 & 932.0007 \\
\hline 14.6 & & & 439.6460 & 226.9189 & 939.0007 \\
\hline 15 & $\mathrm{Fg} 2.2$ & 1 & 49.6321 & 79.8739 & 894.0078 \\
\hline 16 & $\mathrm{Fg} 2.3$ & 1 & 63.6016 & 64.971 & 894.0081 \\
\hline 17 & $\mathrm{Fg} 2.4$ & 1 & 58.3398 & 68.3843 & 894.0087 \\
\hline 18 & $\mathrm{Fg} 2.5$ & 1 & 54.0555 & 67.8305 & 894.0093 \\
\hline 19 & Fg2.6 & 1 & 57.7478 & 69.6462 & 894.0099 \\
\hline 20 & $\mathrm{Fg} 2.7$ & 1 & 57.7478 & 69.6462 & 894.0105 \\
\hline
\end{tabular}

TABEL VI. B

HASIL CENTROID DAN BOUNDING BOX SERTA LUAS AREA DARI SEMUA SAMPEL DARI KAMERA SMART PHONE

\begin{tabular}{|c|c|c|c|c|c|}
\hline \multirow[b]{2}{*}{ No } & \multirow[b]{2}{*}{ Nama } & \multirow[b]{2}{*}{ Jml } & \multicolumn{3}{|c|}{ Citra dari Smart phone } \\
\hline & & & $\begin{array}{c}\text { Centroid } \\
\mathrm{X}\end{array}$ & $\begin{array}{c}\text { Centroid } \\
\text { Y }\end{array}$ & $\begin{array}{c}\text { Area } \\
\text { (pixels) }\end{array}$ \\
\hline 1.1 & \multirow{6}{*}{ Fgl.1 } & \multirow{6}{*}{6} & 292.8959 & 568.9204 & 904.0007 \\
\hline 1.2 & & & 355.0157 & 220.1987 & 911.0007 \\
\hline 1.3 & & & 710.2641 & 239.8899 & 918.0007 \\
\hline 1.4 & & & 745.0192 & 590.7477 & 925.0007 \\
\hline 1.5 & & & 1049.9777 & 285.3849 & 932.0007 \\
\hline 1.6 & & & 1062.4709 & 635.1717 & 939.0007 \\
\hline 2.1 & \multirow{6}{*}{$\mathrm{Fg} 1.2$} & \multirow{6}{*}{6} & 173.9885 & 493.8935 & 904.0172 \\
\hline 2.2 & & & 236.1205 & 145.4728 & 911.0172 \\
\hline 2.3 & & & 591.1339 & 165.1266 & 918.0172 \\
\hline 2.4 & & & 625.9742 & 515.7787 & 925.0172 \\
\hline 2.5 & & & 942.9122 & 560.1518 & 932.0172 \\
\hline 2.6 & & & 930.6876 & 210.4563 & 939.0172 \\
\hline 3.1 & \multirow{4}{*}{$\begin{array}{l}\text { Fgl.3- } \\
1\end{array}$} & \multirow{4}{*}{4} & 182.1202 & 497.9036 & 900.0178 \\
\hline 3.1 & & & 244.2660 & 149.9091 & 907.0178 \\
\hline 3.1 & & & 598.9841 & 169.5474 & 914.0178 \\
\hline 3.1 & & & 633.8627 & 519.8145 & 921.0178 \\
\hline 4.1 & \multirow{4}{*}{$\begin{array}{l}\text { Fgl.3- } \\
2\end{array}$} & \multirow{4}{*}{4} & 133.4126 & 190.2911 & 900.0184 \\
\hline 4.2 & & & 168.1579 & 541.7458 & 907.0184 \\
\hline 4.3 & & & 473.4717 & 236.1255 & 914.0184 \\
\hline 4.4 & & & 486.2604 & 586.2387 & 921.0184 \\
\hline 5.1 & \multirow{3}{*}{$\begin{array}{l}\text { Fg1.4- } \\
1\end{array}$} & \multirow{3}{*}{3} & 184.1370 & 163.4577 & 898.019 \\
\hline 5.2 & & & 539.1412 & 183.1723 & 905.019 \\
\hline 5.3 & & & 878.6145 & 228.4942 & 912.019 \\
\hline
\end{tabular}




\begin{tabular}{|c|c|c|c|c|c|}
\hline \multirow[b]{2}{*}{ No } & \multirow[b]{2}{*}{ Nama } & \multirow[b]{2}{*}{ Jml } & \multicolumn{3}{|c|}{ Citra dari Smart phone } \\
\hline & & & $\begin{array}{c}\text { Centroid } \\
\mathrm{X}\end{array}$ & $\begin{array}{c}\text { Centroid } \\
\text { Y }\end{array}$ & $\begin{array}{c}\text { Area } \\
\text { (pixels) }\end{array}$ \\
\hline 6.1 & \multirow{3}{*}{$\begin{array}{l}\text { Fgl.4- } \\
2\end{array}$} & \multirow{3}{*}{3} & 199.9994 & 167.9337 & 898.0197 \\
\hline 6.2 & & & 651.9805 & 189.7843 & 905.0197 \\
\hline 6.3 & & & 968.9759 & 234.1205 & 912.0197 \\
\hline 7.1 & \multirow{2}{*}{$\begin{array}{l}\text { Fg1.5- } \\
1\end{array}$} & \multirow[b]{2}{*}{2} & 204.1706 & 517.8801 & 903.0203 \\
\hline 7.2 & & & 266.3320 & 170.4073 & 896.0203 \\
\hline 8.1 & \multirow{2}{*}{$\begin{array}{l}\text { Fg1.5- } \\
2\end{array}$} & \multirow{2}{*}{2} & 147.2069 & 191.0129 & 896.0209 \\
\hline 8.2 & & & 181.9956 & 541.7880 & 903.0209 \\
\hline 9.1 & \multirow{2}{*}{$\begin{array}{l}\text { Fgl.5- } \\
3\end{array}$} & \multirow{2}{*}{2} & 152.0125 & 185.9396 & 896.0221 \\
\hline 9.2 & & & 165.1982 & 536.3033 & 903.0221 \\
\hline 10.1 & \multirow{2}{*}{$\begin{array}{l}\text { Fg1.5- } \\
4\end{array}$} & \multirow[b]{2}{*}{2} & 216.2455 & 158.1021 & 896.0227 \\
\hline 10.2 & & & 570.9806 & 177.7725 & 903.0227 \\
\hline 11.1 & \multirow{2}{*}{$\begin{array}{l}\text { Fg1.5- } \\
5\end{array}$} & \multirow{2}{*}{2} & 147.3043 & 166.6927 & 896.0233 \\
\hline 11.2 & & & 487.1154 & 212.2422 & 903.0233 \\
\hline 12.1 & \multirow{2}{*}{$\begin{array}{l}\text { Fg1.5- } \\
6\end{array}$} & \multirow{2}{*}{2} & 208.0643 & 179.9252 & 896.0239 \\
\hline 12.2 & & & 659.9319 & 201.8125 & 903.0239 \\
\hline 13.1 & \multirow{2}{*}{$\begin{array}{l}\text { Fg1.5- } \\
7\end{array}$} & \multirow{2}{*}{2} & 214.0796 & 173.7361 & 896.0245 \\
\hline 13.2 & & & 531.9375 & 218.1827 & 903.0245 \\
\hline 14.1 & \multirow{6}{*}{ Fg2.1 } & \multirow{6}{*}{6} & 292.8959 & 568.9204 & 904.0148 \\
\hline 14.2 & & & 355.0157 & 220.1987 & 911.0007 \\
\hline 14.3 & & & 710.2641 & 239.8899 & 918.0007 \\
\hline 14.4 & & & 745.0192 & 590.7477 & 925.0007 \\
\hline 14.5 & & & 1049.9777 & 285.3849 & 932.0007 \\
\hline 14.6 & & & 1062.4709 & 635.1717 & 939.0007 \\
\hline 15 & Fg2.2 & 1 & 165.3467 & 169.3679 & 894.0258 \\
\hline 16 & $\mathrm{Fg} 2.3$ & 1 & 147.0644 & 151.4181 & 894.0264 \\
\hline 17 & $\mathrm{Fg} 2.4$ & 1 & 168.0700 & 173.8654 & 894.027 \\
\hline 18 & $\mathrm{Fg} 2.5$ & 1 & 171.1812 & 187.8969 & 894.0276 \\
\hline 19 & $\mathrm{Fg} 2.6$ & 1 & 184.0124 & 185.7355 & 894.0282 \\
\hline 20 & $\mathrm{Fg} 2.7$ & 1 & 166.8664 & 198.3283 & 894.0288 \\
\hline
\end{tabular}

Berdasarkan pada gambar 7.(a) dan 7.(b) serta Tabel VI diketahui bahwa luas area (A) yang didapatkan nilai yang sama pada gambar thermal dan gambar dari kamera smart phone. Setelah proses cropping gambar didapatkan nilai dengan setiap cropping memberikan nilai yang berbeda dan semakin kecil cropping memberikan luas Area yang semakin kecil untuk semua data yang telah dilakukan perhitungan seperti pada Tabel VI.A dan VI.B.

\section{KESIMPULAN}

Proses identifikasi objek telur dengan region props dan labelling dapat berhasil dilakukan dengan tingkat keberhasilan $100 \%$. Setiap sampel gambar yang diproses menunjukkan bahwa proses cropping memberikan nilai luas area yang lebih kecil. Selain itu, citra cropping dengan objek yang sedikit (Tabel VI.B) memiliki luas area yang hampir sama (ekuivalen) untuk setiap objek yang sama. Proses identifikasi pada gambar telur ayam dari kamera thermal dan kamera smart phone memberikan nilai luas area yang sama. Akan tetapi pada setiap data cropping dari proses yang dilakukan, gambar dari kamera thermal dan kamera smart phone memberikan nilai yang berbeda. Sehingga proses cropping memberikan perbedaan dalam proses identifikasi telur ayam. Perbedaan dari pengolahan citra dari kamera thermal dan kamera smart phone terletak pada proses preprocessing-nya yaitu gambar dari kamera thermal perlu dilakukan proses komplemen dan gambar dari kamera smart phone perlu dilakukan proses opening sebelum dilakukan proses region props dan labelling untuk mendapatkan objek yang terdidentifikasi. Berdasarkan uraian diatas maka didapatkan grafik seperti pada gambar 8 .

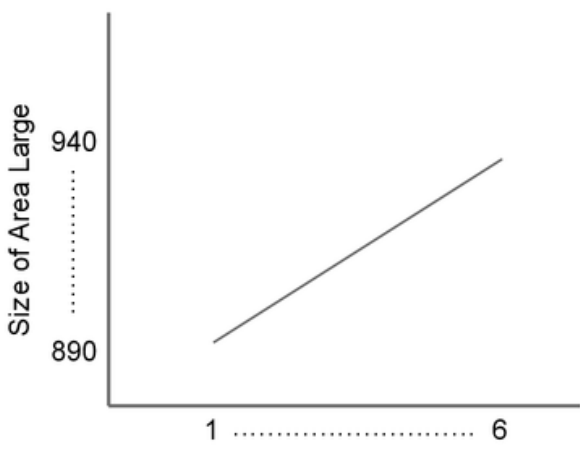

Original Image until Cropping Image

Gambar 8. Grafik Perbandingan Ukuran Luas Area dari Gambar Asli Sampai Cropping 1 Objek

Gambar 8 menunjukkan bahwa setiap ukuran luas area yang dihasilkan memberikan hasil yang signifikan yaitu semakin kecil gambar hasil cropping memberikan nilai luas area semakin kecil juga, sehingga cropping berpengaruh pada luas area pada gambar.

\section{DAFTAR PUSTAKA}

[1] Tridinews, Penjelasan Fungsi dan Kegunaan dari Thermography, $22 / /$ www.news.tridinamika.com, post 14 March 2014

[2] Kamus Besar Bahasa Indonesia Online. http://kbbi.web.id.

[3] INFRATAMA INDONESIA, http://www.infratama.co.id/, copyright 2002 PT. INFRATAMA INDONESIA, Akses 20 Agustus 2016

[4] Utami, Yustina Retno Arum, Pengenalan Telur Berdasarkan Karakteristik Warna Citra, Jurnal Ilmiah SINUS, Vol. 7, No.2, 1-14, ISSN: 1693-1173, (2009).

[5] Wijaya, Tria Adhi, Yudi, Prayudi, Implementasi Visi Komputer Dan Segmentasi Citra Untuk Klasifikasi Bobot Telur Ayam Ras, Seminar Nasional Aplikasi Teknologi Informasi 2010, G1-G5, ISSN: $1907-$ $5022,(20 ! 12$

[6] L. Liu, M. O. Ngadi, Detecting Fertility and Early Embryo Development of Chicken Eggs Using Near-Infrared Hyperspectral Imaging, Springer, Food Bioprocess Technol (2013) 6:2503-2513, 5.12).

[7] Chern-Sheng Lin, Po Ting Yeh, Der-Chin Chen, Yih-Chih Chiou, ChiHung Lee, The Identification and Filtering of Fertilized Eggs with a Thermal Imaging System, Computers and Electronics in Agriculture 91 (2013), 94-105, (2012)

[8] 2 abibulloh, M. Arif, Kusumawardhani, Apriani, Pratama, Detak Yan, Rancang Bangun Sistem Deteksi Embrio pada Telur Menggunakan 14 came, Jurnal Teknik Pomits, Vol. 1, No. 1, 1-6 (2012).

[9] Ruslianto, Ikhwan, Klasifikasi Telur Ayam Dan Telur Burung Puyuh Menggunakan Metode Connected Component Analysis, Jumal Ilmiah SISFOTENIKA, Vol. 3, No. 1, 41-50, (2013). 
[10]Trisnaningtyas, Puspa Rizky. Maimunah, Klasifikasi Mutu Telur Berdasarkan Kebersihan Kerabang Telur Menggunakan K-Nearest Neighbor, Konferensi Nasional Informatika (KNIF), (2015)

[11] 2 rhayati, Oky Dwi, Sistem Analisis Tekstur Secara Statistik Orde 21 ma Untuk Mengenali Jenis Telur Ayam Biasa dan Telur Ayam Omega-3, Jumal Sistem Komputer, Vol. 5, No. 2, 79-82. ISSN: 2087485 , e-ISSN: $2252-3456,(2015)$.

[12] 4 Hai-ling, Cai Jian-rong, Sun Li, Yuan Lei-ming, \& Liu Meng-lei, Research on the Discrimination of Hatching Eggs Activity Based on 4 ermal Imaging: A Food Nondestructive Testing Practice. International Joumal of Smart Home. Vol. 10, No. 2, 175-186, (2016).

[13]Ahmad, U., Pengolahan Citra Digital \& Teknik Pemrogramannya, ed. 1, Yogyakarta: Graha Ilmu, 2005.

[14]Andono, Pulung Nurtantio, Konsep Pengolahan Citra Digital, Ed. 1. Yogyakarta: Andi, (2015),
[15] Metode Algoritma, http://www.metodealgoritma.com/2015/07/metodepenyetaraan-histogram.html

[16] 27 mana, C.J., Implementasi Metode Thresholding dan Metode Regionprops untuk Mendeteksi Marka Jalan Secara Live Video, Jumal 26 Jniversitas Dian Nuswantoro Semarang, 2014

[17] Informatika (Artikel Teknik Informatika dan Sistem Informasi) http://informatika.web.id/operasi-cropping.htm pos 2 Januari 2013

[18] Subiyanto, I., Seri Diktat Kuliah "Metodologi Penelitian". Gunadarma. 1993.

[19] Sunardi, Yudhana, A., Saifullah, S., Thermal Imaging Untuk Identifikasi Telur, Prosiding Konferensi Nasional Ke-4, Asosiasi Program Pascasarjana Perguruan Tinggi Muhammadiyah (APPPTM), hlm. 152-157. 


\section{ANALISIS PERBANDINGAN PENGOLAHAN CITRA ASLI DAN HASIL CROPING UNTUK IDENTIFIKASI TELUR}

ORIGINALITY REPORT

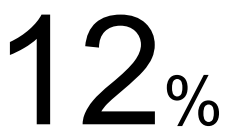

SIMILARITY INDEX

PRIMARY SOURCES

1 zadoco.site Internet

155 words $-3 \%$

2 jsiskom.undip.ac.id Internet

54 words $-1 \%$

3 jurnal.pcr.ac.id Internet

49 words $-1 \%$

4 www.sersc.org Internet

41 words $-1 \%$

5 www.ee.fcu.edu.tw Internet

33 words $-1 \%$

6 nazaruddin.blog.unigha.ac.id Internet

30 words $-1 \%$

7 id.scribd.com Internet

29 words $-<1 \%$

8 journal.uii.ac.id Internet

28 words $-<1 \%$

9 elektro.undip.ac.id Internet

26 words $-<1 \%$

10 www.scribd.com Internet

25 words $-<1 \%$

etheses.uin-malang.ac.id 
12 www.mdpi.com Internet

13 hanifidiani17.blogspot.co.id Internet

14 journals.usm.ac.id Internet

15 ejurnal.stmik-budidarma.ac.id Internet

16 Nuri Ari Efiana, Thi Nhu Quynh Phan, Arko Jatmiko Wicaksono, Andreas Bernkop- Schnürch. "Mucus permeating self-emulsifying drug delivery systems (SEDDS): About the impact of mucolytic enzymes", Colloids and Surfaces B: Biointerfaces, 2018 Crossref

17 sinnaarmianto.blogspot.com Internet

18 kbbi.web.id Internet

19 scholar.uad.ac.id Internet

20 repo.pens.ac.id Internet

21 publikasi.dinus.ac.id Internet

22 repository.uinjkt.ac.id Internet

23 eprints.uny.ac.id Internet
23 words $-<1 \%$

18 words $-<1 \%$

17 words $-<1 \%$

13 words $-<1 \%$
12 words $-<1 \%$

12 words $-<1 \%$

12 words $-<1 \%$

10 words $-<1 \%$

9 words $-<1 \%$

9 words $-<1 \%$

9 words $-<1 \%$ 
24 jurnal-online.um.ac.id

9 words $-<1 \%$

25 ejournals.umn.ac.id

Internet

9 words $-<1 \%$

26 informatika.web.id

Internet

8 words $-<1 \%$

27 kumpulanskripsiekonomis1.wordpress.com

Internet

8 words $-<1 \%$

28 digilib.its.ac.id

Internet

8 words $-<1 \%$

29 skripsi-skripsiun.blogspot.com Internet

8 words $-<1 \%$ 